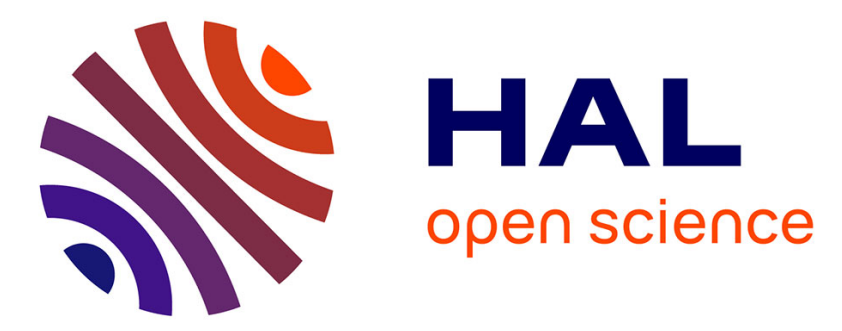

\title{
Chrysin blocks topotecan-induced apoptosis in Caco-2 cells in spite of inhibition of ABC-transporters
}

\author{
Marco Schumacher, Anja Hautzinger, Annette Rossmann, Susanne \\ Holzhauser, Daniela Popovic, Anke Hertrampf, Sabine Kuntz, Michael Boll, \\ Uwe Wenzel
}

\section{To cite this version:}

Marco Schumacher, Anja Hautzinger, Annette Rossmann, Susanne Holzhauser, Daniela Popovic, et al.. Chrysin blocks topotecan-induced apoptosis in Caco-2 cells in spite of inhibition of ABC-transporters. Biochemical Pharmacology, 2010, 80 (4), pp.471. 10.1016/j.bcp.2010.04.038 . hal-00601185

\section{HAL Id: hal-00601185 https://hal.science/hal-00601185}

Submitted on 17 Jun 2011

HAL is a multi-disciplinary open access archive for the deposit and dissemination of scientific research documents, whether they are published or not. The documents may come from teaching and research institutions in France or abroad, or from public or private research centers.
L'archive ouverte pluridisciplinaire HAL, est destinée au dépôt et à la diffusion de documents scientifiques de niveau recherche, publiés ou non, émanant des établissements d'enseignement et de recherche français ou étrangers, des laboratoires publics ou privés. 


\section{Accepted Manuscript}

Title: Chrysin blocks topotecan-induced apoptosis in Caco-2 cells in spite of inhibition of ABC-transporters

Authors: Marco Schumacher, Anja Hautzinger, Annette Rossmann, Susanne Holzhauser, Daniela Popovic, Anke Hertrampf, Sabine Kuntz, Michael Boll, Uwe Wenzel

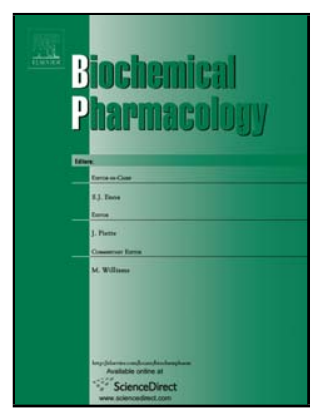

PII: S0006-2952(10)00339-4

DOI: doi:10.1016/j.bcp.2010.04.038

Reference: BCP 10555

To appear in: $\quad B C P$

Received date: 25-3-2010

Revised date: $\quad 29-4-2010$

Accepted date: $\quad 30-4-2010$

Please cite this article as: Schumacher M, Hautzinger A, Rossmann A, Holzhauser S, Popovic D, Hertrampf A, Kuntz S, Boll M, Wenzel U, Chrysin blocks topotecan-induced apoptosis in Caco-2 cells in spite of inhibition of ABC-transporters, Biochemical Pharmacology (2008), doi:10.1016/j.bcp.2010.04.038

This is a PDF file of an unedited manuscript that has been accepted for publication. As a service to our customers we are providing this early version of the manuscript. The manuscript will undergo copyediting, typesetting, and review of the resulting proof before it is published in its final form. Please note that during the production process errors may be discovered which could affect the content, and all legal disclaimers that apply to the journal pertain. 


\section{Chrysin blocks topotecan-induced apoptosis in Caco-2 cells in spite of inhibition of $A B C$-transporters}

Marco Schumacher, Anja Hautzinger, Annette Rossmann, Susanne Holzhauser, Daniela Popovic, Anke Hertrampf, Sabine Kuntz, Michael Boll, and Uwe Wenzel*

Molecular Nutrition Research, Interdisciplinary Research Center, Justus-LiebigUniversity of Giessen, Heinrich-Buff-Ring 26-32, D-35392 Giessen, Germany

${ }^{*}$ Corresponding author at: Molecular Nutrition Research, Interdisciplinary Research

Center, Justus-Liebig-University of Giessen, Heinrich-Buff-Ring 26-32, D-35392

Giessen, Germany. Tel. +49 641/99-39220; fax: +49 641/99-39229.

E-mail address: uwe.wenzel@ernaehrung.uni-giessen.de (U. Wenzel) 
Abbreviations: ABC, ATP binding cassette; Ac-DEVD-CHO, acetyl-aspartyl-glutamylvalyl-aspartyl-aldehyde; Ac-IETD-AFC, acetyl-isoleucyl-glutamyl-threonyl-aspartyl-7amino-4-trifluoromethylcoumarin, AP, alkaline phosphatase; BCECF-AM, 2',7'-bis-(2carboxyethyl)-5-(and 6)-carboxyfluorescein acetoxymethylester; BCRP, Breast cancer resistance protein; CMFDA, 5-chloromethylfluorescein diacetate; DMEM, Dulbecco's Modified Eagle Medium; ECL, Enhanced chemiluminescence; DTT, dithiothreitol; FACS, fluorescence activated cell sorting; FCS, Fetal calf serum; HEPES, N-hydroxyethylpiperazine-N'-2-ethanesulfonate; MDR, Multi drug resistance; MRP, multidrug resistance-associated protein; NEAA, nonessential amino acids; Pgp, P-phosphoglycoprotein; $\mathrm{pH}_{\mathrm{i}}$, intracellular $\mathrm{pH}$; TBS-T, Tris-buffered saline-Tween; Z-DEVD-AMC, carboxybenzoxy-aspartyl-glutamyl-valyl-aspartyl-amino-4-methylcoumarine. 


\section{Abstract}

ATP-driven efflux pumps such as phosphoglycoprotein-170 (P-gp), multidrug resistance-associated protein-2 (MRP-2), or breast cancer resistance protein (BCRP) play a crucial role in limiting the efficacy of tumor pharmacotherapy. Selected flavonoids have been suggested to inhibit individual efflux-transporters and to act therefore as multidrug-resistance reversing agents. In the present study it is shown that the flavonoid chrysin acts as a potent inhibitor of P-gp, MRP-2, and BCRP in Caco-2 colon carcinoma cells. As a consequence, cells accumulated higher rates of the apoptosis-inducing chemotherapeutic topotecan in the presence of chrysin, even though under these conditions the expression of the transporters was markedly increased. Interestingly, in spite of the enhanced cellular drug accumulation the topotecan-induced apoptosis, assessed according to DNA-fragmentation, chromatin condensation, and by determination of sub-G1 peaks using fluorescence-assistedcell sorting (FACS), was potently inhibited by chrysin. Suggested transport independent apoptosis inhibiting activities of ATP-binding cassette (ABC)transporters, such as the inhibition of caspases, were shown to be necessary for the inhibition of topotecan-induced apoptosis and were found to be associated with stabilization of ß-catenin especially in the cytosol. Inhibition of topotecan-induced intracellular acidification, however, was proven not to prevent caspase activation and apoptosis.

In conclusion, our studies show that chrysin in spite of raising the cellular concentrations of topotecan potently inhibits the apoptosis-inducing activities of the anti-tumor drug. Inhibition of caspase-activation was identified as the underlying mechanism and is suggested to be caused by transport-independent functions of ABC-transporters.

Key words: ABC-transporters, apoptosis, caspases, topotecan, chrysin, ß-catenin 


\section{Introduction}

Phosphoglycoprotein-170 (P-gp), multidrug resistance-associated protein-2 (MRP-2), and breast cancer resistance protein (BCRP) are ATP-binding cassette (ABC) transporters located at the apical membrane of enterocytes that may drive their substrates from inside the cell back into the intestinal lumen [1,2]. Those substrates encompass various synthetic and natural lipophilic compounds [2-4]. Moreover, the inhibitor specificities of P-gp, BCRP and MRP-2 were shown to be highly overlapping, and general inhibitors of $A B C$ transporters were more lipophilic and aromatic than specific inhibitors and non-inhibitors [5]. Whereas the physiological role of $A B C$ transporters might be to reduce the body load of potentially harmful compounds [2] their overexpression in tumors confers a multi-drug resistance (MDR) phenotype to cancer cells [6,7]. In vitro screening has identified a number of pharmaceuticals which can selectively inhibit pumps such as P-gp, by virtue of their being substrates for these pumps [8]. However, several generations of pharmaceutical inhibitors of P-gp have been examined in preclinical and clinical studies and these circumvention trials have largely failed to demonstrate the anticipated increase in therapeutic efficacy [8]. At least in part this may be due to the redundancy of efflux pumps in resistant cancer cells but transport independent mechanisms could also account for this "multifactorial multidrug resistance" [9].

Besides the affection of $A B C$ transporters by drugs they can be modulated by ingredients of plant foods or herbal products such as the flavonoids [10]. In that context, influences of several flavonoids have been demonstrated to be exerted at the level of expression, posttranslational modification, or transport function [10]. The latter can be influenced through an effect on the transporters' ATPase activity. Both, stimulation, e.g. by glabridin, and inhibition, e.g. by genistein and quercetin, have 
been described [11,12]. Another possible mechanism for flavonoid-mediated inhibition of $\mathrm{ABC}$-transporters is by competitive inhibition when flavonoids act as substrates $[10,13]$. Whereas the free aglycones appear to be mainly transported by P-gp, intracellularly formed glucuronidated and sulfated conjugates can be transported by MRP-2 and BCRP $[10,14,15]$.

In the present study, we tested in Caco-2 human colon carcinoma cells the influence of the flavonoid chrysin, contained in honey, propolis and fruit skin [10], on the transport of fluorescent substrates for P-gp, MRP-2, and BCRP, respectively. By Western Blotting we determined the impact of chrysin on the expression level of the transporters. The net effect on transport activity was estimated then by measuring the accumulation of the anti-tumor drug topotecan. DNA-fragmentation was quantified as a measure of topotecan-induced apoptosis and estimations of caspase-activities and $\mathrm{pH}_{\mathrm{i}}$ served the discovery of the mechanisms underlying alterations in the apoptosis rate. Immunocytochemistry detecting ß-catenin in fixed Caco-2 cells was finally performed in order to associate the effects of chrysin on apoptosis and differentiation with cellular localization of this transcription factor whose deregulation is intimately linked to tumor formation [16]. 


\section{Materials and methods}

\subsection{Materials}

Chrysin, fluorescent substrates (except CMFDA) and inhibitors of ABC transporters were purchased from Sigma (Deisenhofen, Germany). CMFDA was from Invitrogen (Karlsruhe, Germany). Cell culture plates were from Renner (Dannstadt, Germany). All other materials needed for cell culture, SYTOX-Green, BCECF-AM, and EnzChek ${ }^{\circledR}$ Kit for measuring caspase activities were from Invitrogen (Karlsruhe, Germany). Topotecan was from Molekula (Lisses, France). Quadriperm wells were from Greiner Bio-one (Frickenhausen, Germany). DNase free RNase was from MBI Fermentas (Heidelberg, Germany). Caspase-8 substrate Ac-IETD-AFC, caspase-8 inhibitor Ac-IETD-CHO, and mouse-anti-ß-catenin were from BD Biosciences (Heidelberg, Germany). Rabbit-anti-P-gp, mouse-anti-MRP-2, mouse-anti-BCRP, mouse-anti-actin, and horseradish peroxidase labeled goat-anti-mouse-lgG and goatanti-rabbit-lgG antibodies were from Santa Cruz Biotechnology (Heidelberg, Germany). Biotinylated anti-mouse-lgG was obtained from Vector Laboratories (Munich, Germany) and FluoroLink Cy5 labeled streptavidin by Amersham Biosciences (Freiburg, Germany). The Bio-Rad-Protein-Assay was purchased from BioRad (Munich, Germany). All other chemicals were obtained from Sigma (Deisenhofen, Germany).

\subsection{Cell culture}

Caco-2 cells (HTB 37, passage 31) were provided by American Type Culture Collection (ATCC) and were used between passages 40 and 65 . Cells were cultured 
and passaged in DMEM supplemented with 10\% FCS, 2 mM glutamine, 1\% MEM non essential amino acids and $70 \mu \mathrm{g} / \mathrm{ml}$ gentamycin in a humidified incubator at $37^{\circ} \mathrm{C}$ under an atmosphere of $5 \% \mathrm{CO}_{2}$. Cells were passaged at preconfluent densities by the use of a solution containing $0.05 \%$ trypsin and $0.5 \mathrm{mM}$ EDTA.

\subsection{P-gp, MRP-2 and BCRP mediated transport of topotecan}

For estimation of the $\mathrm{ABC}$-transporters activities the fluorescent dyes rhodamine 123, CMFDA, and Hoechst 33342 were used at $1 \mu \mathrm{M}$ concentrations as substrates for P-gp [17], MRP-2 [18], and BCRP [19], respectively. Contributions of the respective transporters for overall transport were verified by using the selective inhibitors verapamil, MK-571, and fumitremorgin C [20]. Cells were exposed to substrates in Krebs buffer $\left(137 \mathrm{mM} \mathrm{NaCl}, 5.4 \mathrm{mM} \mathrm{KCl}, 2.8 \mathrm{mM} \mathrm{CaCl}_{2}, 1 \mathrm{mM} \mathrm{MgSO}\right.$, $10 \mathrm{mM}$ glucose, $10 \mathrm{mM}$ HEPES, $\mathrm{pH}$ 7.4) for $3 \mathrm{~h}$ over which transport of the substrates was linear. Thereafter cells were washed twice with ice-cold Krebs buffer and fluorescence of rhodamine 123 and CMFDA was measured at emission of 538 $\mathrm{nm}$ after excitation at $485 \mathrm{~m}$, whereas emission of Hoechst 33342 was estimated at $460 \mathrm{~nm}$ after excitation at $355 \mathrm{~nm}$ using a microtiter plate reader (Fluoroskan Ascent, Thermo Electron, Dreieich, Germany). The accumulation of topotecan was assessed according to its fluorescent properties with excitation at $355 \mathrm{~nm}$ and emission at 538 $\mathrm{nm}[21]$.

\subsection{Apoptosis assays}

Caspase-3 and -8 activities were determined using the EnzChek activity assay Kit according to the manufacturer's instructions. In brief, $0.5 \times 10^{6}$ cells per well were 
seeded onto 6-well plates and allowed to adhere for $48 \mathrm{~h}$. Cells were then exposed for $24 \mathrm{~h}$ to the test compounds. Subsequently, cells were trypsinized, cell numbers were determined and then the cells were pelleted for $5 \mathrm{~min}$ at $300 \times \mathrm{g}$. The pellets were suspended in $50 \mu \mathrm{l}$ of lysis buffer and centrifuged at $45.000 \times \mathrm{g}$ for $5 \mathrm{~min}$. Cleavage of Z-DEVD-AMC (final concentration $100 \mu \mathrm{M}$ ) was followed in the fluorometer by excitation at $355 \mathrm{~nm}$ and emission of $460 \mathrm{~nm}$ each $20 \mathrm{~min}$ over $5 \mathrm{~h}$. For inhibition of caspase-3 Ac-DEVD-CHO was added. For determination of caspase8 activities Ac-IETD-AFC (final concentration $100 \mu \mathrm{M}$ ) was used. Cleavage of the substrate was followed by measuring emission at $538 \mathrm{~nm}$ after excitation at $355 \mathrm{~nm}$.

Nuclear fragmentation as a late marker of apoptosis was determined by staining of DNA with SYTOX-Green nucleic acid stain. Cells $\left(1 \times 10^{6}\right)$ were seeded onto glass slides and incubated in Quadriperm wells with the test compounds for 48 h. Thereafter glass slides were washed with PBS and cells were fixed with $2 \%$ paraformaldehyde. DNA was stained with $0.25 \mu \mathrm{M}$ SYTOX-Green solution and visualized under an epifluorescence microscope (Zeiss Axioskope 2) equipped with a band path excitation filter of $470 \mathrm{~nm}$ and a long path emission filter of $520 \mathrm{~nm}$. Photographs were made from at least three independent cell batches and apoptotic cells were determined according to the number of cells displaying chromatin condensation and nuclear fragmentation versus total cell counts.

FACS-analysis was performed in order to quantify the amount of cells with significantly lower amounts of intact DNA which appear as a subG1-peak as a characteristic of apoptosis. Therefore, Caco-2 cells were seeded at a density of $1 \mathrm{x}$ $10^{6}$ onto $25 \mathrm{~cm}^{2}$ culture flasks and were incubated for $48 \mathrm{~h}$ in the presence or the absence of the test compounds after having reached $40 \%$ confluency. Cells were trypsinized, pelleted by centrifugation at $500 \times g$ for 3 min, washed twice with PBS and adjusted to $1 \times 10^{6} \mathrm{cells} / \mathrm{ml}$. Cells were then fixed by suspending them at $4^{\circ} \mathrm{C}$ in 
ethanol for $24 \mathrm{~h}$. Thereafter, the suspension was centrifuged for $3 \mathrm{~min}$ at $500 \mathrm{xg}$, and the pellet was washed twice in $38 \mathrm{mM}$ sodium citrate buffer $(\mathrm{pH} 7.4)$. After washing and centrifugation, cells were incubated with the dye solution containing 7-amino actin $(1 \mathrm{mg} / \mathrm{ml}), 1 \mathrm{U}$ of DNase free RNase in sodium citrate buffer. Cell cycle analysis was performed using a FACScan (Becton Dickinson, San Jose, CA, U.S.A.) and the Lysis II Ver. 1.1 software.

\subsection{Differentiation assay}

$0.5 \times 10^{6}$ Caco- 2 cells were seeded onto $25 \mathrm{~cm}^{2}$-culture flasks and thereafter incubated for $48 \mathrm{~h}$ with the test compounds. Cells were washed twice with PBS and trypsinized and the harvested cells were pelleted for $10 \mathrm{~min}$ at $1500 \mathrm{~g}$. The pellets were resuspended in $1 \mathrm{M}$ diethanolamine buffer, $\mathrm{pH} 9.8$ with $0.5 \mathrm{mM} \mathrm{MgCl}_{2}$ and homogenized. $50 \mu \mathrm{l}$ of the homogenate were mixed with $940 \mu$ l diethanolamine buffer and $10 \mu \mathrm{l}$ AP substrate 4-nitrophenol phosphate (1.25 mM stock solution). AP-activity was calculated according to UV-absorption of the product 4-nitrophenol which absorbs light at $405 \mathrm{~nm}$.

\section{6. $p H_{i}$-measurements}

For $\mathrm{pH}_{\mathrm{i}}$-measurements cells were loaded with BCECF by preincubating the cells with $5 \mu \mathrm{M}$ of the lipophilic acetoxymethyl-ester (BCECF-AM) at $37^{\circ} \mathrm{C}$ for $45 \mathrm{~min}$. Subsequently the monolayers were washed with Krebs buffer, $\mathrm{pH}$ 7.4. Prior to $\mathrm{pH}_{\mathrm{i}^{-}}$ measurements the medium was taken off from the cells and was reapplied directly after measurements. This proceeding was chosen in order to simulate the conditions used for apoptosis measurements and moreover, to neglect influences on $\mathrm{pH}_{\mathrm{i}}$-measurements by 
BCECF diffusing out of the cells during these long periods. Intracellular $\mathrm{H}^{+}$-activity was determined by measuring the intensity of emission at $538 \mathrm{~nm}$ after excitation of the fluorophore at $444 \mathrm{~nm}$ (isosbestic point) and $485 \mathrm{~nm}$ ( $\mathrm{pH}$-sensitive wavelength), respectively, using the microtiter plate reader. The 485/444 fluorescence ratio was converted to $\mathrm{pH}_{\mathrm{i}}$ from a calibration curve generated by estimation of the fluorescence ratio in buffers of different $\mathrm{pH}[22]$.

\subsection{Western blotting}

Caco-2 cells were incubated in $75 \mathrm{~cm}^{2}$ flasks and scraped off in ice-cold PBS containing $0.2 \%$ EDTA. Cells were pelleted subsequently by centrifugation for $5 \mathrm{~min}$ at $300 \mathrm{~g}$. The pelleted cells were dissolved subsequently in lysis buffer $(10 \mathrm{mM}$ HEPES, $1 \mathrm{mM}$ EDTA, $1 \mathrm{mM}$ DTT, $0.2 \%$ protease inhibitor cocktail, $\mathrm{pH}$ 7.5) and frozen overnight at $-80^{\circ} \mathrm{C}$. Thereafter, cells were homogenized by 20 strokes with a Teflon homogenizer. Samples were centrifuged for $20 \mathrm{~min}$ at $380 \mathrm{~g}$ to remove intact cells and the supernatant was centrifuged at $40.000 \times \mathrm{g}$ for $20 \mathrm{~min}$ in order to enrich the plasma membrane fraction. The final pellet was resuspended in membrane buffer (10 mM HEPES, 10\% glycerol, $1 \mathrm{mM}$ EDTA, $1 \mathrm{mM}$ DTT, 0.2\% protease inhibitor cocktail) and protein content was determined by the Bradford reaction.

The proteins of the membrane fractions were resolved by SDS-PAGE according to the method described by Schagger and von Jagow [23] and were electroblotted onto PVDF membranes. Control of protein transfer and identification of the molecular weight marker proteins was achieved by Ponceau Red staining. Thereafter, the blotting membranes were blocked for $1 \mathrm{~h}$ with TBS-T containing $1 \%$ milk powder and then incubated for $1 \mathrm{~h}$ with the primary antibodies recognizing P-gp (1:500), MRP-2 (1:50), and BCRP (1:50), respectively. Blots were washed three 
times with TBS-T and bound antibodies were detected after $1 \mathrm{~h}$ incubation with horseradish peroxidase conjugated secondary antibodies $(1: 1000)$ using an ECL system according to the manufacturer's instructions.

\subsection{Immunocytochemistry}

For immunofluorescent detection of ß-catenin, cells grown on poly-L-lysine coated glass slides were fixed by $2 \%$ paraformaldehyde for $10 \mathrm{~min}$ on ice. Thereafter, cells were incubated for $2 \mathrm{~h}$ in a humidity chamber with a 1:500 dilution of anti-ßcatenin. After washing four times with TBS-T, adding for $1 \mathrm{~h}$ biotinylated anti-mouseIgG in a 1:200 dilution and washing twice with TBS-T and TBS, respectively, bound antibodies were detected using FluoroLinkCy5 labeled streptavidin in a 1:500 dilution. Cell nuclei were stained by $0.25 \mu \mathrm{M}$ SYTOX-Green solution during a 15 min incubation. Antibody staining was detected at an emission of $645-720 \mathrm{~nm}$ after excitation at $633 \mathrm{~nm}$, and SYTOX-Green nucleic acid stain at emissions of 500-535 $\mathrm{nm}$ after excitation at $488 \mathrm{~nm}$ by confocal laser scanning microscopy (DMIRBE Leica, Wetzlar, Germany).

\subsection{Calculations and statistics}

All calculations were performed by using Prism 4.01 (Graph PAD, Los Angeles, CA). For each variable 4-8 independent experiments were carried out. Data are given as the mean \pm S.E.M. Variance analysis between groups was performed by One-way ANOVA and significance of differences between control and treated cells were determined by a Tukey's test. 


\section{Results}

3.1. Chrysin inhibits P-gp, MRP-2, and BCRP in Caco-2 cells and increases the accumulation of topotecan

To test the influence of chrysin on $A B C$-transporters its impact on the accumulation of P-gp substrate rhodamine 123, the MRP-2 substrate CMFDA, and the BCRP-substrate Hoechst 33342 were estimated. Chrysin dose-dependently increased the accumulation of the P-gp substrate rhodamine 123, the MRP-2 substrate CMFDA, and the BCRP-substrate Hoechst 33342 with very similar $\mathrm{EC}_{50^{-}}$ values around $50 \mu \mathrm{M}$ (Fig. 1A). Maximum accumulations of the substrates in the presence of $250 \mu \mathrm{M}$ chrysin, moreover, were very similar to those achieved by the specific transport-inhibitors verapamil for P-gp, MK-571 for MRP-2, and fumitremorgin for BCRP, respectively (Fig. 1B). Moreover, in the presence of specific inhibitors $250 \mu \mathrm{M}$ chrysin was not able to enhance the accumulation of the fluorescent dyes significantly (data not shown), suggesting that transport of the substrates by the respective transporters under the conditions used is rather specific.

None of the three inhibitors was able to increase the accumulation of the topoisomerase-I inhibitor topotecan as potently as did chrysin (Fig. 2A). However, equal accumulation potency could be achieved when all three inhibitors were coadministered (Fig. 2A). Moreover, the dose-dependent accumulation increase of topotecan by chrysin revealed an $\mathrm{EC}_{50}$-value of $68.6 \pm 0.8 \mu \mathrm{M}$ which is in the range of the $\mathrm{EC}_{50}$-values observed for chrysin with regard to the inhibition of P-gp, MRP-2, and BCRP (Fig. 2B). 


\subsection{Chrysin increases the expression of ABC-transporters in Caco-2 cells}

The increased accumulation of topotecan observed in the presence of chrysin suggests the flavonoid to be a MDR-reversing agent. In this regard, however, effects on the expression rates must be considered as well especially concerning longer periods of treatment. Western blotting experiments revealed that chrysin enhanced significantly the expression of all three ABC-transporters as did topotecan (Fig. 3AC). More importantly, chrysin was able to stimulate transporter expression even in the presence of topotecan (Fig. 3A-C). Over a time period of $48 \mathrm{~h}$, however, the inhibition of transporter function prevails to the enhanced expression as accumulation of topotecan was still increased by chrysin at this time point of incubation (Fig. 3D).

\subsection{Chrysin inhibits potently topotecan-induced apoptosis}

Surprisingly, chrysin almost completely abolished topotecan-induced chromatin condensation and DNA-fragmentation as markers of proceeded apoptosis (Fig. 4A). On the basis of these apoptosis markers dose-response relationships revealed a half maximal inhibition of topotecan-mediated apoptosis at $128 \mu \mathrm{M}$ (Fig. 4B). Moreover, FACS analysis showed that $48 \%$ of the cell population were present in a sub-G - $_{1}$-peak caused by fragmented DNA in apoptotic cells after topotecan treatment (Fig. 4C). Accordingly, the FACS analysis verified the results obtained by microscopic assessment of apoptotic nuclei. Besides the fact that chrysin almost completely inhibited topotecan-induced apoptosis when assessed by FACS, it could be shown that the flavonoid arrests cells in $G_{2} / M$ as this population increases from $8 \%$ in the control to $25 \%$ in chrysin treated cells (Fig. 4C). Finally, not only apoptosis as a cancer preventive parameter was inhibited but also differentiation. Whereas 
neither topotecan nor chrysin affected differentiation in Caco-2 cells, chrysin efficiently inhibited differentiation when triggered by butyrate (Fig. 4D).

\subsection{Chrysin inhibits the topotecan-mediated activation of caspases- 3 and -8}

According to data showing that transport-independent effects of P-gp exist on caspase-activities we tested whether up-stream caspase-8 and effector-caspase-3 were modulated by chrysin. Indeed chrysin was able to potently inhibit topotecanmediated caspase-8 and caspase-3 activation (Fig. 5A). One of the postulated mechanisms through which this inhibition could be achieved is via increasing $\mathrm{pH}_{\mathrm{i}}$. However, chrysin did not significantly affect topotecan-induced intracellular acidification, nor did the base imidazole inhibit caspase-activation and apoptosis although it prevented the topotecan-induced $\mathrm{pH}_{\mathrm{i}}$-decline (Fig. 5B).

\subsection{Chrysin stabilizes cytosolic ß-catenin}

Since both caspase- 8 and -3 were shown in previous studies to be involved in processing of cytosolic ß-catenin, processed ß-catenin was detected by Western blotting (Fig. 6A) and localization of this cancer promoting transcription factor was studied by immunocytochemistry (Fig. 6B). It could be shown that topotecan cleaves ß-catenin whereas chrysin stabilizes ß-catenin in the cytosol (Fig. 6A). Moreover, chrysin caused a removal of $ß$-catenin from the plasma membrane into the cytosol as did topotecan and the same was visible when both compounds were combined (Fig. 6B). These results suggest that stabilized cytosolic ß-catenin might transmit the effects of chrysin on inhibition of apoptosis. In this context it was demonstrated that 
inhibition of the downstream caspase-3 not only prevented topotecan-induced cleavage of ß-catenin (Fig. 6C) but also apoptosis as caused by topotecan (Fig. 6D). 


\section{Discussion}

Multi-drug resistance is a phenomenon based on various adaptations of cancer cells to escape the killing actions of chemotherapeutics [24]. On a molecular level those adaptations are exemplified by immune-escape mechanisms [25], the overexpression of detoxifying enzymes of phase-I or -II metabolism [26], or the enhanced expression of $A B C$-transporters [27]. The overexpression of $A B C$ transporters promotes the outward-transport of most commonly used cancer drugs in spite of their different chemical structures and thereby prevents the achievement of effective drug concentrations in the target cells. This causes an immense clinical problem and consequently there has been intense search for compounds which can act to reverse MDR phenotype in cultured cells, in animal models, and ultimately in patients [28]. Within this search a number of natural compounds were identified that interact with $\mathrm{ABC}$-transporters, and in contrast to the first generation MDR-reversing agents, which were usually drugs, have been regarded to possess fewer side effects [28]. Amongst those compounds, many flavonoids appear to serve as substrates of the $A B C$-transporters P-gp, MRP-2, and BCRP and thus may reverse MDR by competitive inhibition [10]. On the other hand, we have shown in a previous study that selected flavonoids were able to increase P-gp expression in human colorectal cancer cells in vitro and in the mouse intestine in vivo [29]. Whereas in normal cells induced expression of $A B C$-transporters might serve the excretion of the inducing xenobiotic, i.e. the flavonoid, in cancer cells MDR could derive.

Using human Caco-2 cells as an in vitro model for colorectal cancer we demonstrate in the present study that the flavonoid chrysin, occurring abundantly in fruit skins [10], is able to inhibit three apical ABC-transporters, i.e. P-gp, MRP-2, and BCRP, dose-dependently. The chemotherapeutic topotecan appears to be extruded 
from Caco-2 cells by all three transporters since specific inhibitors for P-gp, MRP-2, and BCRP, respectively, resulted in similar increases in the accumulation of the drug, whereas the higher rate of accumulation caused by chrysin was achieved only when all three inhibitors were applied simultaneously. Chrysin consequently appeared to meet the criteria of an effective MDR-reversing agent by efficient blockade of topotecan efflux. Moreover, those effects can be expected to occur under in vivo conditions as well since concentrations of polyphenols in the low mM range may be considered as plausible in the gut lumen after ingestion of a normal diet rich in fruits and vegetables [30,31]. Obviously the inhibition of transport by chrysin prevails versus the also observed increased expression of all three efflux-pumps since increased accumulation of topotecan could still be detected after $48 \mathrm{~h}$ of incubation when transporters had already been up-regulated. Therefore it was quite astonishing that in spite of increased topotecan accumulation the apoptosis-inducing activities of topotecan, quantified after $48 \mathrm{~h}$, were completely inhibited by chrysin. Since beyond apoptosis, differentiation is another crucial parameter which has been shown to be diminished in cancer cells [32], we also tested whether chrysin has influence on differentiation of Caco-2 cells. Certain dietary compounds, such as butyrate from fiber, have been shown in culture selectively to promote and restore differentiation in neoplastic cells and, thereby, have the potential to eliminate aberrant cells at an early stage of tumor formation [33]. As shown in many studies before, butyrate efficiently induced differentiation in Caco-2 cells. Notably, beyond blocking topotecan-induced apoptosis chrysin greatly diminished differentiation as caused by butyrate.

The apoptosis inhibiting activities of chrysin might be due to the enhanced expression of ABC-transporters. This assumption is derived from experiments in cells which were transfected with mutant P-gp. It was demonstrated that the transportdeficient P-gp potently reduced caspase activities [34] in accordance with our 
observations that apoptosis was inhibited by chrysin instead of inhibition of transport activities and the concomitant enhanced topotecan levels observed inside Caco-2 cells. Moreover, classical multidrug resistant human tumor cell lines expressing high levels of P-gp were less sensitive to multiple forms of caspase-dependent cell death, including that mediated by ligation of Fas [35]. Since caspase-activation requires intracellular acidification [36] and moreover, P-gp was suggested to act anti-apoptotic by prevention of a decline in $\mathrm{pH}_{\mathrm{i}}[37,38]$, we first tested whether chrysin has an impact on $\mathrm{pH}_{\mathrm{i}}$. Chrysin did not affect the diminished $\mathrm{pH}_{\mathrm{i}}$ which was caused by topotecan thus excluding that the inhibition of caspase- 3 and -8 by chrysin was due to a stabilizaton of $\mathrm{pH}_{\mathrm{i}}$. Moreover, preventing the topotecan-induced $\mathrm{pH}_{\mathrm{i}}$-decline by addition of the base imidazole did not inhibit the ability of topotecan to activate caspases- 8 and -3 , supporting that a low $\mathrm{pH}_{\mathrm{i}}$ is not necessary for caspase activation in Caco-2 cells.

Inhibition of apoptosis has been described to be mediated by ß-catenin, a transcription factor of the Wnt-signaling pathway which is disregulated in colon cancer development $[39,40]$. Since $ß$-catenin can be degraded by the downstream effector caspase-3 [41,42] we finally assessed the impact of chrysin on ß-catenin stability but also on its intracellular localization. Degradation of this tumor-promoting factor, as caused by topotecan, was clearly inhibited by chrysin. On the other hand, cellular localization of ß-catenin, which was found predominantly in the cytosol and nuclei of topotecan-treated cells, was not affected by chrysin. Since a caspase-3inhibitor prevented the degradation of $ß$-catenin and also apoptosis it must be suggested that stabilization of ß-catenin is the prime mechanism underlying the enhancing effects of chrysin on cancer cell survival. This is in agreement with studies concluding that an important function of ß-catenin cleavage during apoptosis is the removal of its transcription activation [41]. The stabilization of $ß$-catenin might finally 
be transmitted into enhanced expression of the investigated $A B C$-transporters as it was shown for P-gp in brain endothelial cells that its promoter can be activated by $ß$ catenin signaling [43]. Since expression of BCRP and MRP-2 increased under activation of canonical Wnt/ß-catenin signaling as well [43] it can be suggested that stabilized ß-catenin activates a number of $\mathrm{ABC}$-transporters by promoter activation. In addition to apoptosis, ß-catenin was shown in Caco-2 cells to influence differentiation $[44,45]$. In this regard the enhanced localization of $ß$-catenin in the plasma membrane was associated with increased differentiation $[44,45]$. Butyrate was shown in colon cancer cells to cause sequestration of $ß$-catenin to the cell membrane as well, suggesting that a possible role of butyrate is to promote differentiation via increasing the levels of ß-catenin available for cell adhesion [46]. However, that $ß$-catenin is directly involved in differentiation of Caco-2 cells is rather unlikely since butyrate in our experiments resulted in identical localization and fragmentation patterns of $ß$-catenin as topotecan and whereas both compounds are potent apoptosis inducers (not shown for butyrate), only butyrate led to an increase in differentiation. On the other hand it can not be excluded that chrysin exerts its differentiation inhibiting activities via ß-catenin stabilization and a concomitant increase in $\mathrm{ABC}$-transporter expression since indeed a role for $\mathrm{P}$-gp in regulating cellular differentiation has been postulated given the down-regulation of endogenous P-gp expression during differentiation of pluripotent stem cells [47].

In conclusion, our studies show that the enhanced expression of three ABCtransporters in human colorectal cancer cells by the flavonoid chrysin is associated with prevention of topotecan-induced apoptosis. This inhibition of apoptosis occurs in spite of increased drug accumulation that is caused by the inhibition of transport activities. The most plausible explanation for the observed effects is provided by the inhibition of caspases which protects ß-catenin from caspase-mediated cleavage. 
The direct mechanisms through which $\mathrm{ABC}$-transporters can affect $\mathrm{pH}_{\mathrm{i}}$, caspase activities, and finally apoptosis remain to be elucidated. 


\section{Acknowledgements}

This study was supported by the Deutsche Forschungsgemeinschaft; Grant number: WE 2684/7-1 and 7-2. The authors greatly acknowledge the expert technical assistance of Mrs. Eva Czynski. We are indebted to Mr. Alan McDonley for critically reading the manuscript. 


\section{References}

[1] Dietrich CG, Geier A, Oude Elferink RP. ABC of oral bioavailability: transporters as gatekeepers in the gut. Gut 2003;52:1788-95.

[2] Chan LM, Lowes S, Hirst BH. The ABCs of drug transport in intestine and liver: efflux proteins limiting drug absorption and bioavailability. Eur J Pharm Sci 2004;21:25-51.

[3] Suzuki H, Sugiyama $Y$. Single nucleotide polymorphisms in multidrug resistance associated protein 2 (MRP2/ABCC2): its impact on drug disposition. Adv Drug Deliv Rev 2002;54:1311-31.

[4] Doyle LA, Ross DD. Multidrug resistance mediated by the breast cancer resistance protein BCRP (ABCG2). Oncogene 2003;22:7340-58.

[5] Matsson P, Pedersen JM, Norinder U, Bergström CA, Artursson P. Identification of novel specific and general inhibitors of the three major human ATP-binding cassette transporters P-gp, BCRP and MRP2 among registered drugs. Pharm Res 2009;26:1816-31.

[6] Murakami T, Takano M. Intestinal efflux transporters and drug absorption. Expert Opin Drug Metab Toxicol 2008;4:923-39.

[7] Zhou SF. Structure, function and regulation of P-glycoprotein and its clinical relevance in drug disposition. Xenobiotica 2008;38:802-32.

[8] O'Connor R. The pharmacology of cancer resistance. Anticancer Res 2007;27:1267-72.

[9] Su Y, Lee SH, Sinko PJ. Inhibition of efflux transporter ABCG2/BCRP does not restore mitoxantrone sensitivity in irinotecan-selected human leukemia CPT-K5 cells: evidence for multifactorial multidrug resistance. Eur J Pharm Sci 2006;29:102-10.

[10] Alvarez AI, Real R, Pérez M, Mendoza G, Prieto JG, Merino G. Modulation of the activity of $\mathrm{ABC}$ transporters (P-glycoprotein, MRP2, BCRP) by flavonoids and drug response. J Pharm Sci 2009;99:598-617.

[11] Cao J, Chen X, Liang J, Yu XQ, Xu AL, Chan E, Wei D, Huang M, Wen JY, Yu XY, Li XT, Sheu FS, Zhou SF. Role of P-glycoprotein in the intestinal absorption of glabridin, 
an active flavonoid from the root of Glycyrrhiza glabra. Drug Metab Dispos 2007;35:539-53.

[12] Pulido MM, Molina AJ, Merino G, Mendoza G, Prieto JG, Alvarez Al. Interaction of enrofloxacin with breast cancer resistance protein (BCRP/ABCG2): Influence of flavonoids and role in milk secretion in sheep. J Vet Pharmacol Ther 2006;9:279-87.

[13] Wang Y, Cao J, Zeng S. Involvement of Pglycoprotein in regulating cellular levels of Ginkgo flavonols: Quercetin, kaempferol, and isorhamnetin. J Pharm Pharmacol 2005;57:751-758.

[14] Vaidyanathan JB, Walle T. Transport and metabolism of the tea flavonoid (-)epicatechin by the human intestinal cell line Caco-2. Pharm Res 2001:18:1420-1425.

[15] Brand W, van der Wel PA, Rein MJ, Barron D, Williamson G, van Bladeren PJ, Rietjens IM. Metabolism and transport of the citrus flavonoid hesperetin in Caco-2 cell monolayers. Drug Metab Dispos 2008;36:1794-1802.

[16] Näthke I. Cytoskeleton out of the cupboard: colon cancer and cytoskeletal changes induced by loss of APC. Nat Rev Cancer 2006;6:967-74.

[17] van der Sandt IC, Blom-Roosemalen MC, de Boer AG, Breimer DD. Specificity of doxorubicin versus rhodamine-123 in assessing P-glycoprotein functionality in the LLCPK1, LLC-PK1:MDR1 and Caco-2 cell lines. Eur J Pharm Sci 2000;11:207-14.

[18] Förster F, Volz A, Fricker G. Compound profiling for ABCC2 (MRP2) using a fluorescent microplate assay system.Eur J Pharm Biopharm 2008;69:396-403.

[19] Hooijberg JH, Peters GJ, Kaspers GJ, Wielinga PR, Veerman AJ, Pieters R, Jansen G. Online fluorescent method to assess BCRP/ABCG2 activity in suspension cells. Nucleosides Nucleotides Nucleic Acids 2004;23:1451-4.

[20] Li H, Jin HE, Kim W, Han YH, Kim DD, Chung SJ, Shim CK. Involvement of Pglycoprotein, multidrug resistance protein 2 and breast cancer resistance protein in the transport of belotecan and topotecan in Caco-2 and MDCKII cells. Pharm Res 2008;25:2601-12. 
[21] Gryczynski I, Gryczynski Z, Lakowicz JR, Yang D, Burke TG. Fluorescence spectral properties of the anticancer drug topotecan by steady-state and frequency domain fluorometry with one-photon and multi-photon excitation. Photochem Photobiol $1999 ; 69: 421-8$.

[22] Boyarsky G, Hanssen C, Clyne LA. Inadequacy of high $\mathrm{K}+/$ nigericin for calibrating BCECF. II. Intracellular $\mathrm{pH}$ dependence of the correction. Am $\mathrm{J}$ Physiol 1996;271:C1146-56.

[23] Schagger $H$, von Jagow G. Tricine-sodium dodecyl sulfate-polyacrylamide gel electrophoresis for the separation of proteins in the range from 1 to $100 \mathrm{kDa}$. Anal. Biochem 1987; 166,368-79.

[24] Pajak B, Orzechowski A. Overview how adenocarcinoma cancer cells avoid immuneand chemotherapy-induced apoptosis. Adv Med Sci 2006;51:39-45.

[25] Begley J, Ribas A. Targeted therapies to improve tumor immunotherapy. Clin Cancer Res 2008;14:4385-91.

[26] Moscow JA, Cowan KH. Multidrug resistance. J Natl Cancer Inst 1988;80:14-20.

[27] Stavrovskaya AA, Stromskaya TP. Transport proteins of the ABC family and multidrug resistance of tumor cells. Biochemistry 2008;73:592-604.

[28] Lee $\mathrm{CH}$. Reversing agents for ATP-binding cassette drug transporters. Methods Mol Biol 2010;596:325-40.

[29] Lohner K, Schnäbele K, Daniel H, Oesterle D, Rechkemmer G, Göttlicher M, Wenzel U. Flavonoids alter P-gp expression in intestinal epithelial cells in vitro and in vivo. Mol Nutr Food Res 2007;51:293-300.

[30] Serra A, Macià A, Romero MP, Valls J, Bladé C, Arola L, Motilva MJ. Bioavailability of procyanidin dimers and trimers and matrix food effects in in vitro and in vivo models. $\mathrm{Br}$ J Nutr 2010;103:944-52.

[31] Sergent T, Garsou S, Schaut A, De Saeger S, Pussemier L, Van Peteghem C, Larondelle Y, Schneider YJ. Differential modulation of ochratoxin A absorption across 
Caco-2 cells by dietary polyphenols, used at realistic intestinal concentrations. Toxicol Lett 2005;159:60-70.

[32] van der Flier LG, Clevers H. Stem cells, self-renewal, and differentiation in the intestinal epithelium. Annu Rev Physiol 2009;71:241-60.

[33] Wong JM, de Souza R, Kendall CW, Emam A, Jenkins DJ. Colonic health: fermentation and short chain fatty acids. J Clin Gastroenterol 2006;40:235-43.

[34] Tainton KM, Smyth MJ, Jackson JT, Tanner JE, Cerruti L, Jane SM, Darcy PK, Johnstone RW. Mutational analysis of P-glycoprotein: suppression of caspase activation in the absence of ATP-dependent drug efflux. Cell Death Differ 2004;11:1028-37.

[35] Smyth MJ, Krasovskis E, Sutton VR, Johnstone RW. The drug efflux protein, Pglycoprotein, additionally protects drug-resistant tumor cells from multiple forms of caspase-dependent apoptosis. Proc Natl Acad Sci 1998;95:7024-9.

[36] Matsuyama S, Llopis J, Deveraux QL, Tsien RY, Reed JC: Changes in intramitochondrial and cytosolic $\mathrm{pH}$ : early events that modulate caspase activation during apoptosis. Nature Cell Biol 2000;2:318-25.

[37] Robinson LJ, Roberts WK, Ling TT, Lamming D, Sternberg SS, Roepe PD. Human MDR 1 protein overexpression delays the apoptotic cascade in Chinese hamster ovary fibroblasts. Biochemistry 1997;36:11169-78.

[38] Johnstone RW, Ruefli AA, Smyth MJ. Multiple physiological functions for multidrug transporter P-glycoprotein? Trends Biochem Sci 2000;25:1-6.

[39] Shitashige M, Hirohashi S, Yamada T. Wnt signaling inside the nucleus. Cancer Sci 2008;99:631-7.

[40] Gavert N, Ben-Ze'ev A. beta-Catenin signaling in biological control and cancer. J Cell Biochem 2007;102:820-8.

[41] Steinhusen U, Badock V, Bauer A, Behrens J, Wittman-Liebold B, Dörken B, Bommert K. Apoptosis-induced cleavage of beta-catenin by caspase- 3 results in proteolytic fragments with reduced transactivation potential. J Biol Chem 2000;275:16345-53. 
[42] Maier TJ, Janssen A, Schmidt R, Geisslinger G, Grösch S. FASEB J 2005;19:1353-5. Targeting the beta-catenin/APC pathway: a novel mechanism to explain the cyclooxygenase-2-independent anticarcinogenic effects of celecoxib in human colon carcinoma cells.

[43] Lim JC, Kania KD, Wijesuriya H, Chawla S, Sethi JK, Pulaski L, Romero IA, Couraud PO, Weksler BB, Hladky SB, Barrand MA. Activation of beta-catenin signalling by GSK3 inhibition increases p-glycoprotein expression in brain endothelial cells. J Neurochem 2008;106:1855-65.

[44] Mariadason JM, Bordonaro M, Aslam F, Shi L, Kuraguchi M, Velcich A, Augenlicht LH. Down-regulation of beta-catenin TCF signaling is linked to colonic epithelial cell differentiation. Cancer Res 2001;61:3465-71.

[45] Kirkland SC. Type I collagen inhibits differentiation and promotes a stem cell-like phenotype in human colorectal carcinoma cells. Br J Cancer 2009;101:320-6.

[46] Vincan E, Leet CS, Reyes NI, Dilley RJ, Thomas RJ, Phillips WA. Sodium butyrateinduced differentiation of human LIM2537 colon cancer cells decreases GSK-3beta activity and increases levels of both membrane-bound and Apc/axin/GSK-3beta complex-associated pools of beta-catenin. Oncol Res 2000;12:193-201.

[47] Chaudhary PM, Roninson IB. Expression and activity of P-glycoprotein, a multidrug efflux pump, in human hematopoietic stem cells. Cell 1991;66:85-94. 


\section{Figure legends:}

Fig. 1. Chrysin inhibits ABC-transporters in Caco-2 cells. Cells were incubated $3 \mathrm{~h}$ in the presence of $1 \mu \mathrm{M}$ rhodamine 123, CMFDA, or Hoechst 33342 and increasing concentrations of chrysin. Substrate accumulations were quantified subsequently based on their fluorescent properties (A). Increases in accumulation of substrates for $\mathrm{ABC}$ transporters as caused by $250 \mu \mathrm{M}$ chrysin were similar as those in the presence of specific inhibitors, such as $40 \mu \mathrm{M}$ verapamil for P-gp, $50 \mu \mathrm{M}$ MK-571 for MRP-2, or $10 \mu \mathrm{M}$ fumitremorgin for BCRP, respectively. ${ }^{* * *} P<0.001$ versus control.

Fig. 2. Chrysin enhances the accumulation of topotecan. Caco-2 cells were incubated for $3 \mathrm{~h}$ with $25 \mu \mathrm{M}$ topotecan in the absence (control) or presence of $40 \mu \mathrm{M}$ verapamil, $50 \mu \mathrm{M}$ MK-571, $10 \mu \mathrm{M}$ fumitremorgin, or $250 \mu \mathrm{M}$ chrysin, respectively. Topotecan was quantified according to its spectrofluorometric characteristics. ${ }^{*} P<$ $0.05,{ }^{* *} P<0.01$, and ${ }^{* * *} P<0.001$ versus cells exposed to topotecan alone (A). Accumulation of $25 \mu \mathrm{M}$ topotecan was in addition assessed as a function of chrysin concentrations (B).

Fig. 3. Chrysin increases the expression of $A B C$-transporters in the presence of topotecan. Cells were exposed for $48 \mathrm{~h}$ to medium alone (control) or in addition to $250 \mu \mathrm{M}$ chrysin, $25 \mu \mathrm{M}$ topotecan, or a combination of chrysin and topotecan. Thereafter, membrane fractions were enriched, proteins extracted and separated by SDS-PAGE before blotted proteins were probed with specific antibodies for P-gp (A), MRP-2 (B), or BCRP (C) (left panels). Intensities of bands were assessed as described in the Methods section and are given in the right panels. $\#^{\star} P<0.05$, and $\#^{* *} P<0.001$ versus topotecan treated cells $(A-C)$. The topotecan accumulation was 
estimated according to its autofluorescent properties after $48 \mathrm{~h}$ incubation in the absence (control) or presence of $250 \mu \mathrm{M}$ chrysin (D). ${ }^{* *} P<0.05$ versus control.

Fig. 4. Apoptosis and differentiation of Caco-2 cells is inhibited by chrysin. Apoptosis in the presence of medium alone (control) or of $250 \mu \mathrm{M}$ chrysin, $25 \mu \mathrm{M}$ topotecan, or chrysin plus topotecan was calculated after $48 \mathrm{~h}$ incubation according to the percentage of cells showing signs of chromatin condensation and DNA-fragmentation (arrows). $\#^{* \star} P<0.001$ versus topotecan exposed cells $(\mathrm{A})$. The dose-response of the inhibition of topotecan-induced apoptosis by chrysin is given in (B). FACS-analysis was performed to verify the results derived from microscopic evaluations of apoptosis and was done for cells incubated with $250 \mu \mathrm{M}$ chrysin, or $25 \mu \mathrm{M}$ topotecan, or a combination of both (C). The numbers in (C) refer to sub- $\mathrm{G}_{1}(1), \mathrm{G}_{0} / \mathrm{G}_{1}(2), \mathrm{S}(3)$, and $\mathrm{G}_{2} / \mathrm{M}(4)$ phases, respectively. As a positive control for differentiation the effects of 1 $\mathrm{mM}$ and $5 \mathrm{mM}$ butyrate were tested on the AP-activity after $48 \mathrm{~h}$ incubation. In addition the influence of $250 \mu \mathrm{M}$ chrysin on AP-activity was assessed in the absence or presence of butyrate. Topotecan at $25 \mu \mathrm{M}$ did not affect AP-activity. $\#^{* * *} P<0.0001$ versus cells treated with identical butyrate concentrations alone (D).

Fig. 5. Chrysin inhibits topotecan-induced activation of caspase-3 and -8. Activities of caspase- 3 and caspase- 8 in extracts generated from cells that were exposed to medium alone (control), to $25 \mu \mathrm{M}$ topotecan, or a combination of topotecan and 250 $\mu \mathrm{M}$ chrysin or $10 \mathrm{mM}$ imidazole were estimated after $24 \mathrm{~h}$ by measuring the fluorescence generated by cleavage of Z-DEVD-AMC and Ac-IETD-AFC, respectively. $\#^{* * *} P<0.0001$ versus topotecan treated cells $(A)$. Intracellular $\mathrm{pH}$ was recorded according to the fluorescence of BCECF-AM loaded cells and changes of $\mathrm{pH}_{\mathrm{i}}$ were monitored after the addition of either $25 \mu \mathrm{M}$ topotecan or in addition $250 \mu \mathrm{M}$ 
Fig. 1
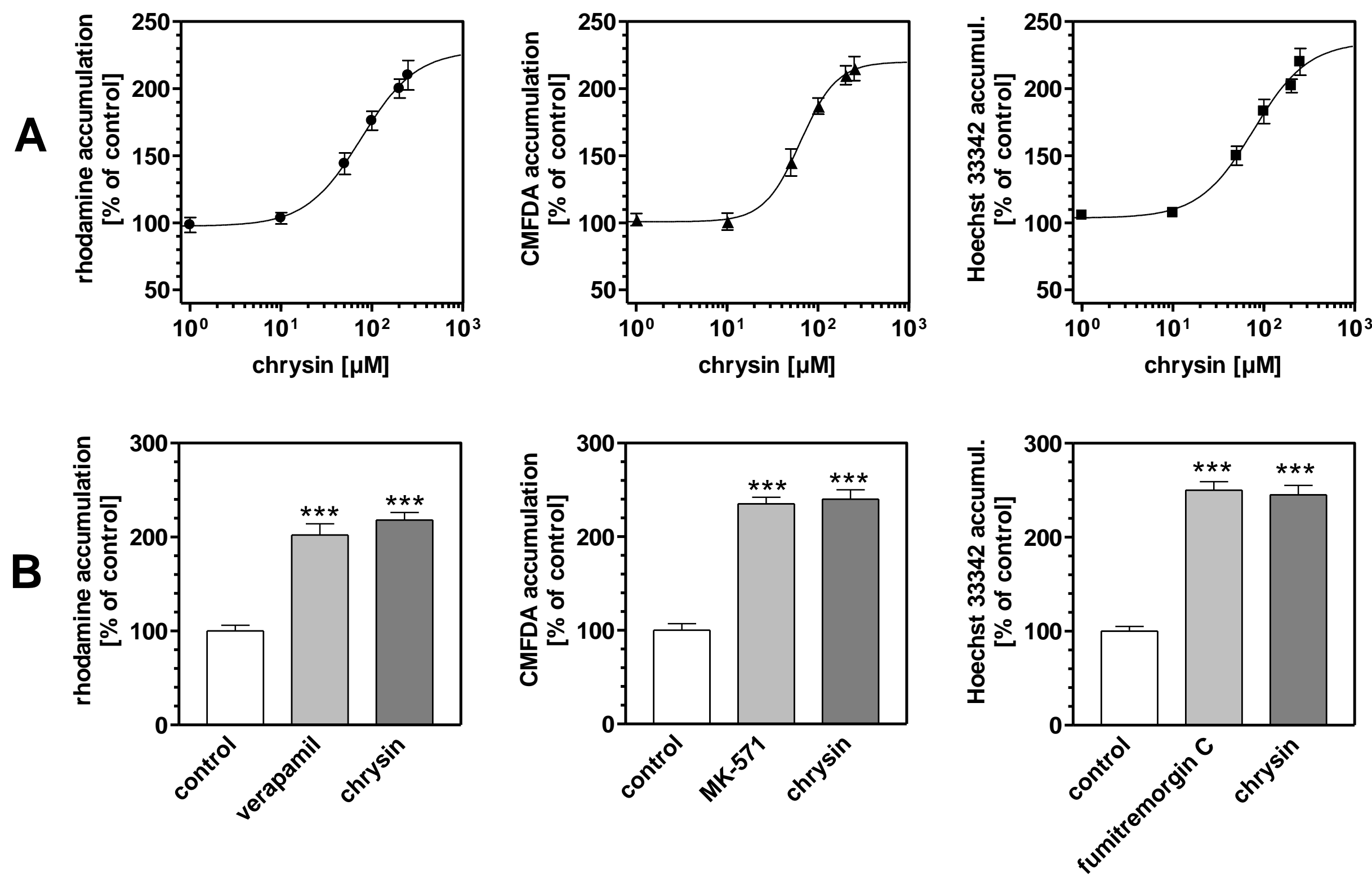
Fig. 2

A
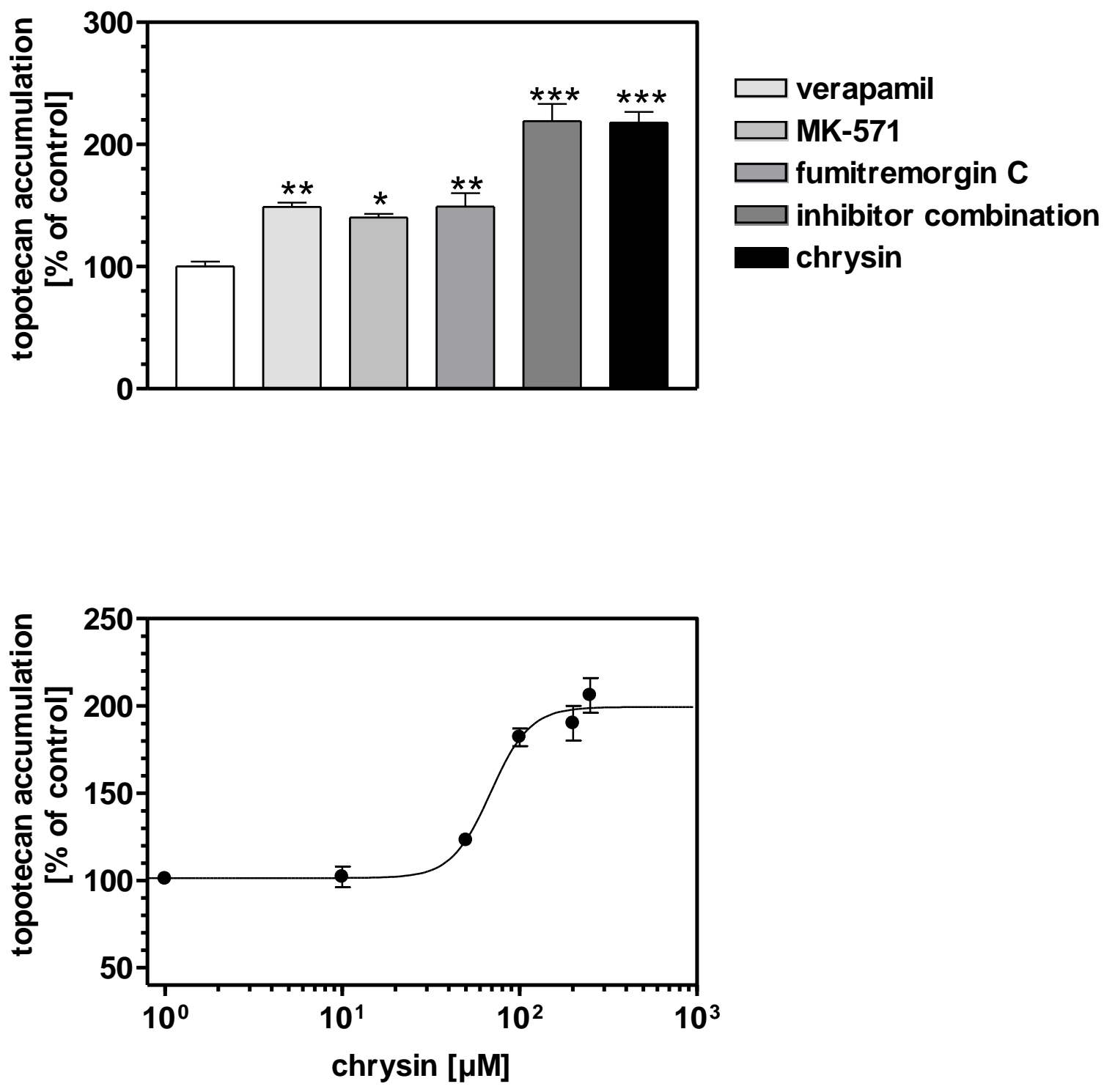
A
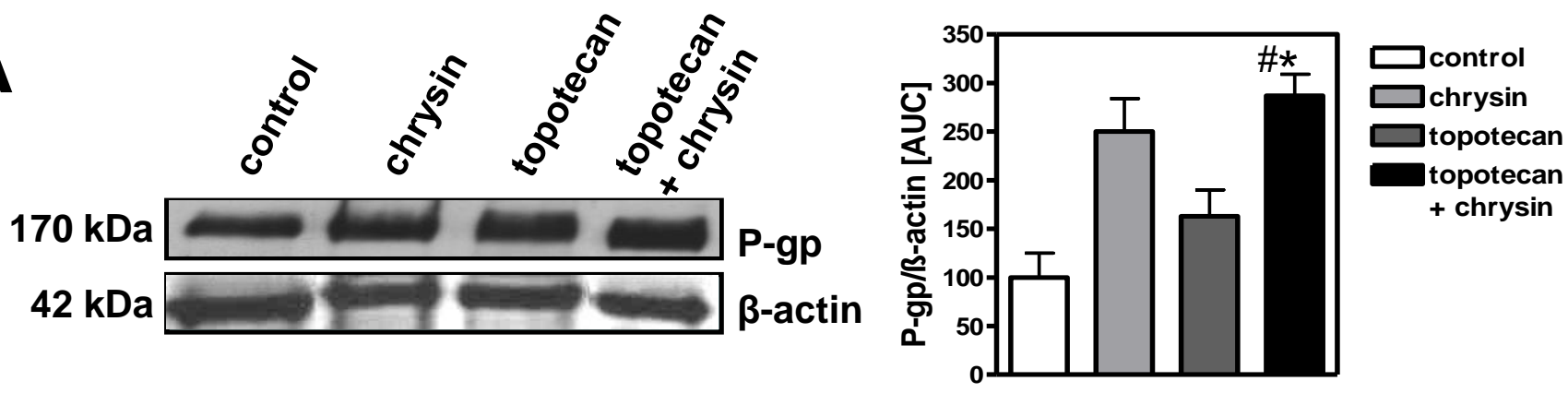

B
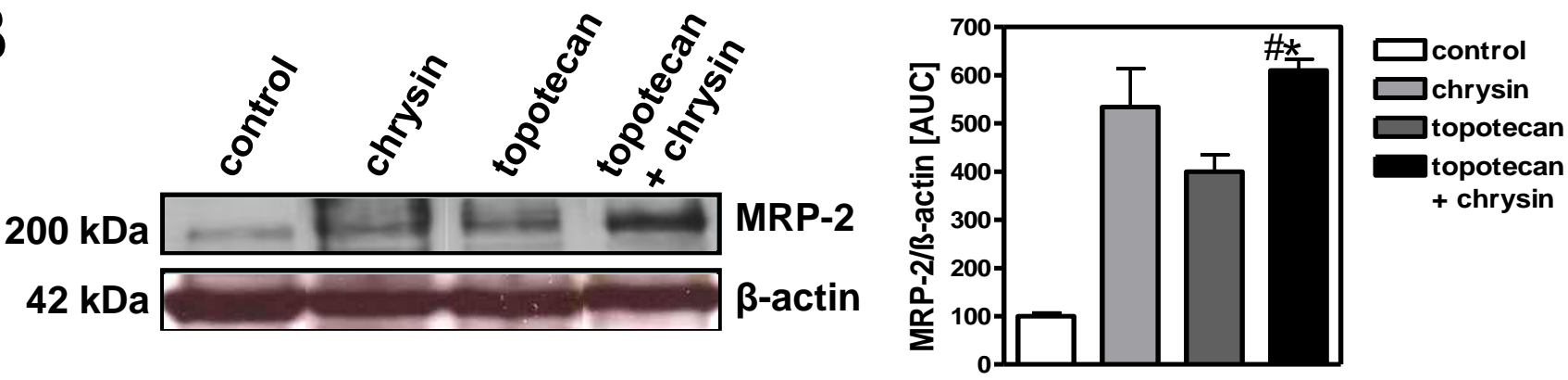

c
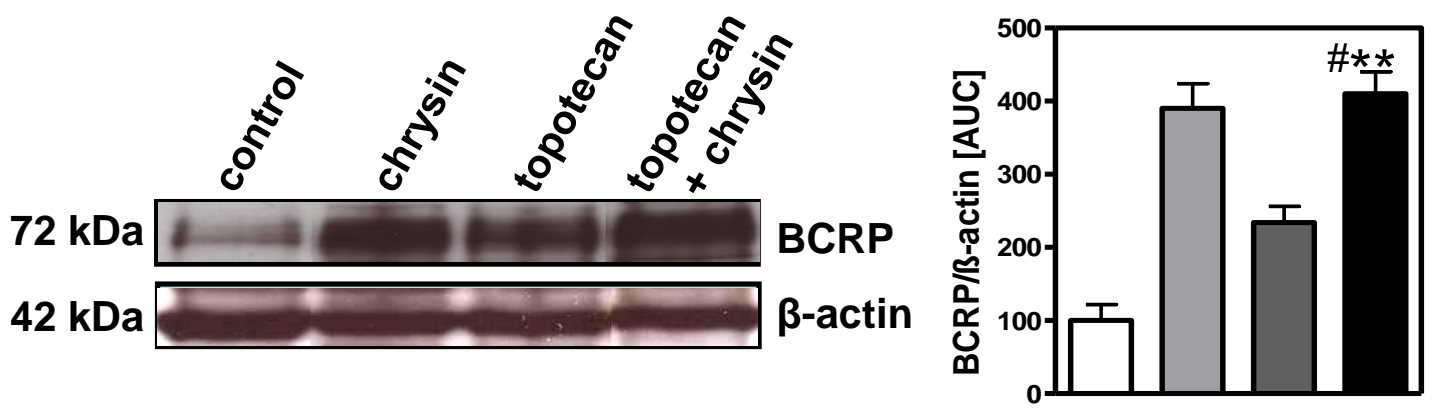

$\square$ control

$\square$ chrysin

$\square$ topotecan

topotecan

+ chrysin

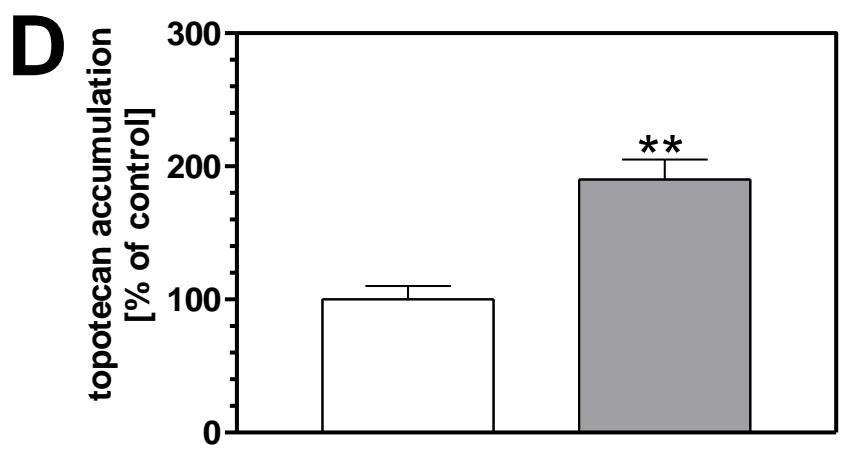

control

$\square$ chrysin 

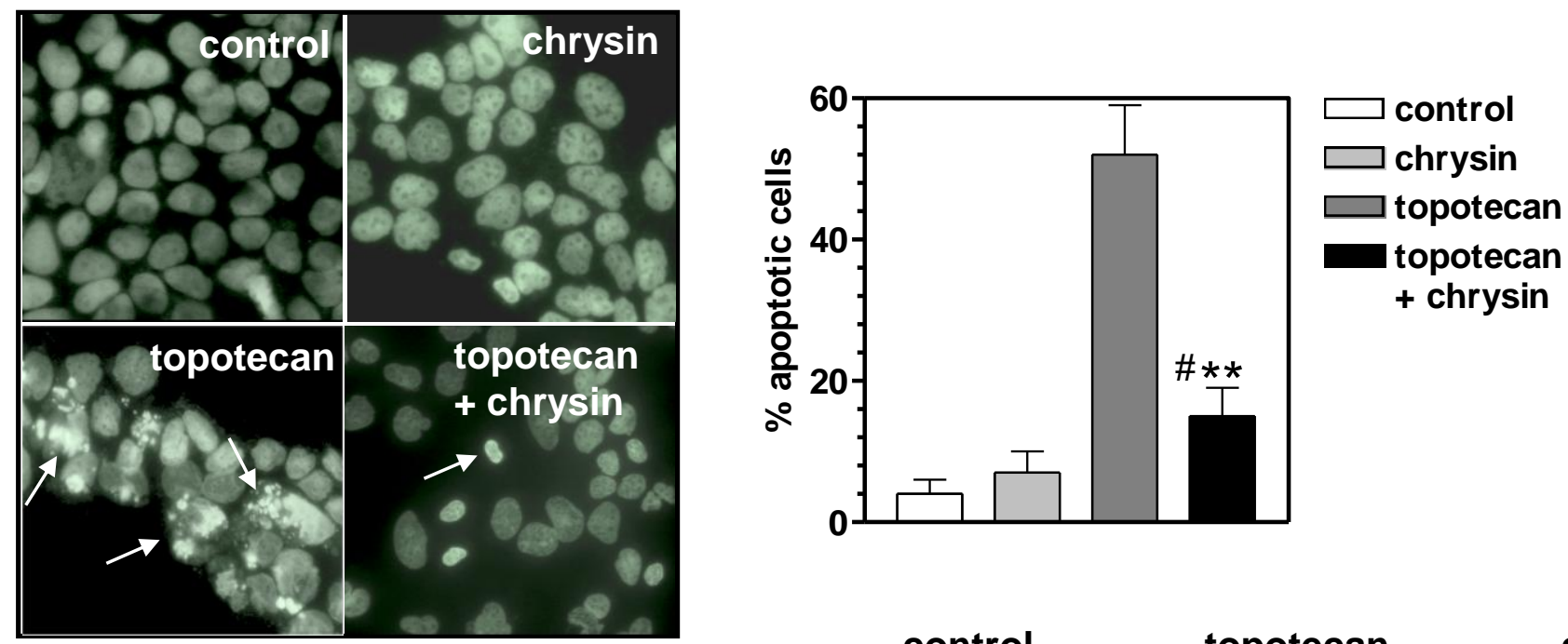

Fig. 4

B

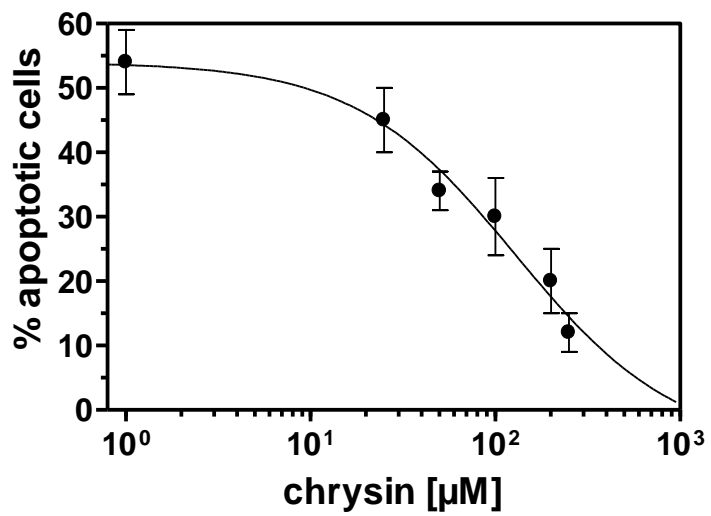

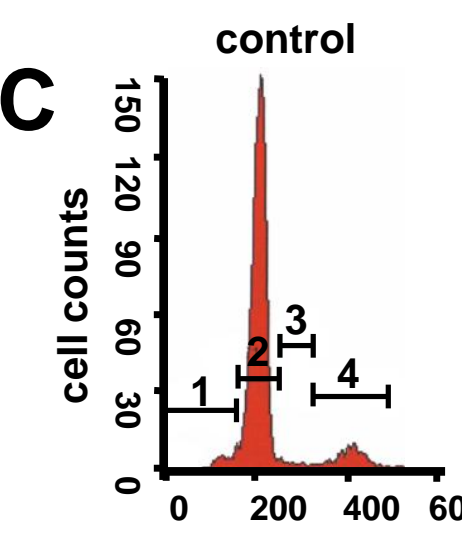

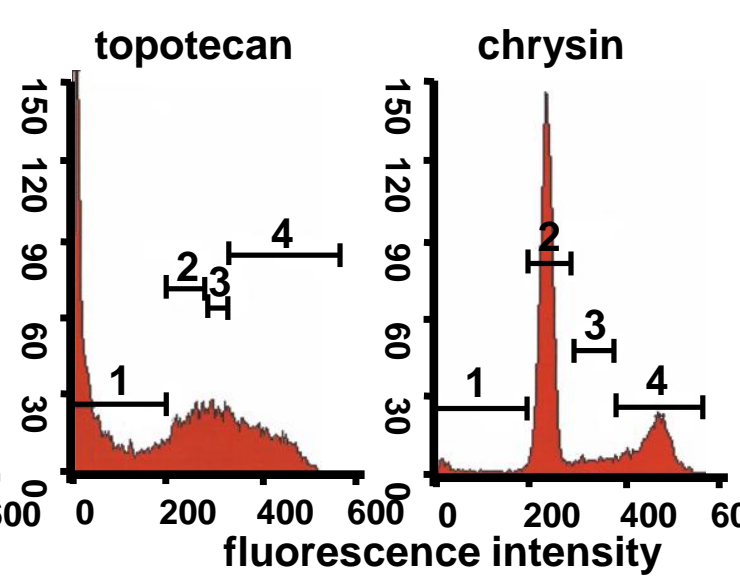

topotecan + chrysin

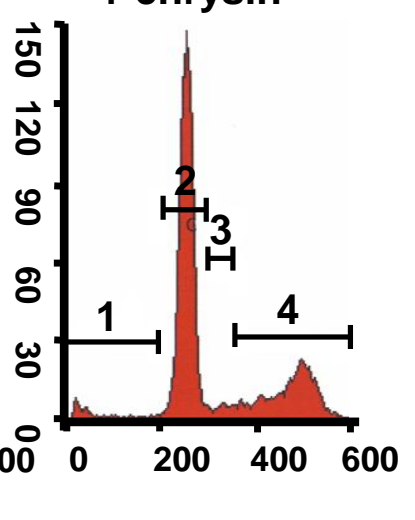

D

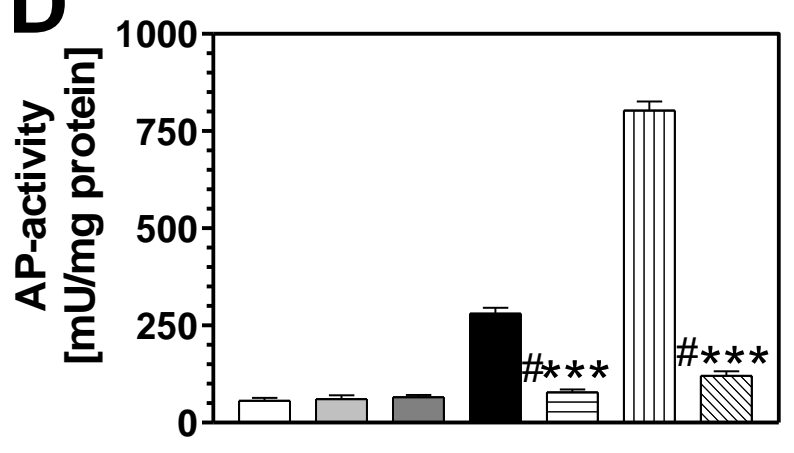

$\square$ control

$\square$ topotecan

$\square$ chrysin

butyrate 1mM

$\Xi$ butyrate $1 \mathrm{mM}$ + chrysin

m butyrate $5 \mathrm{mM}$

butyrate $5 \mathrm{mM}$

+ chrysin 
A

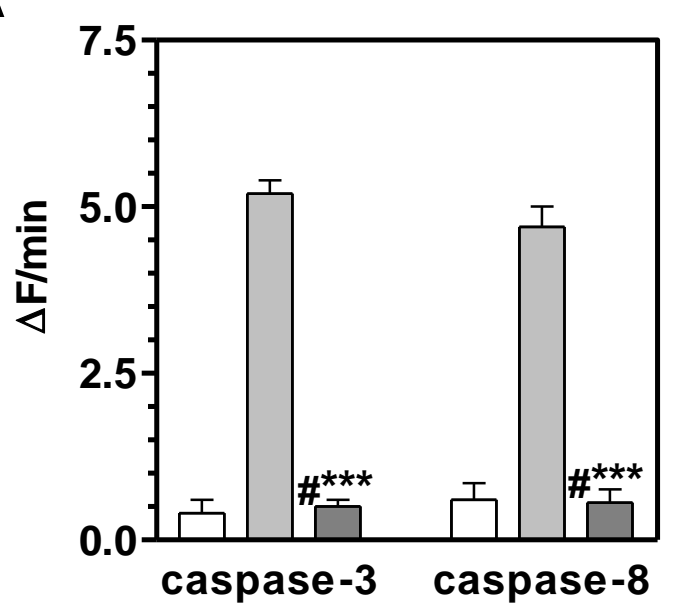

C
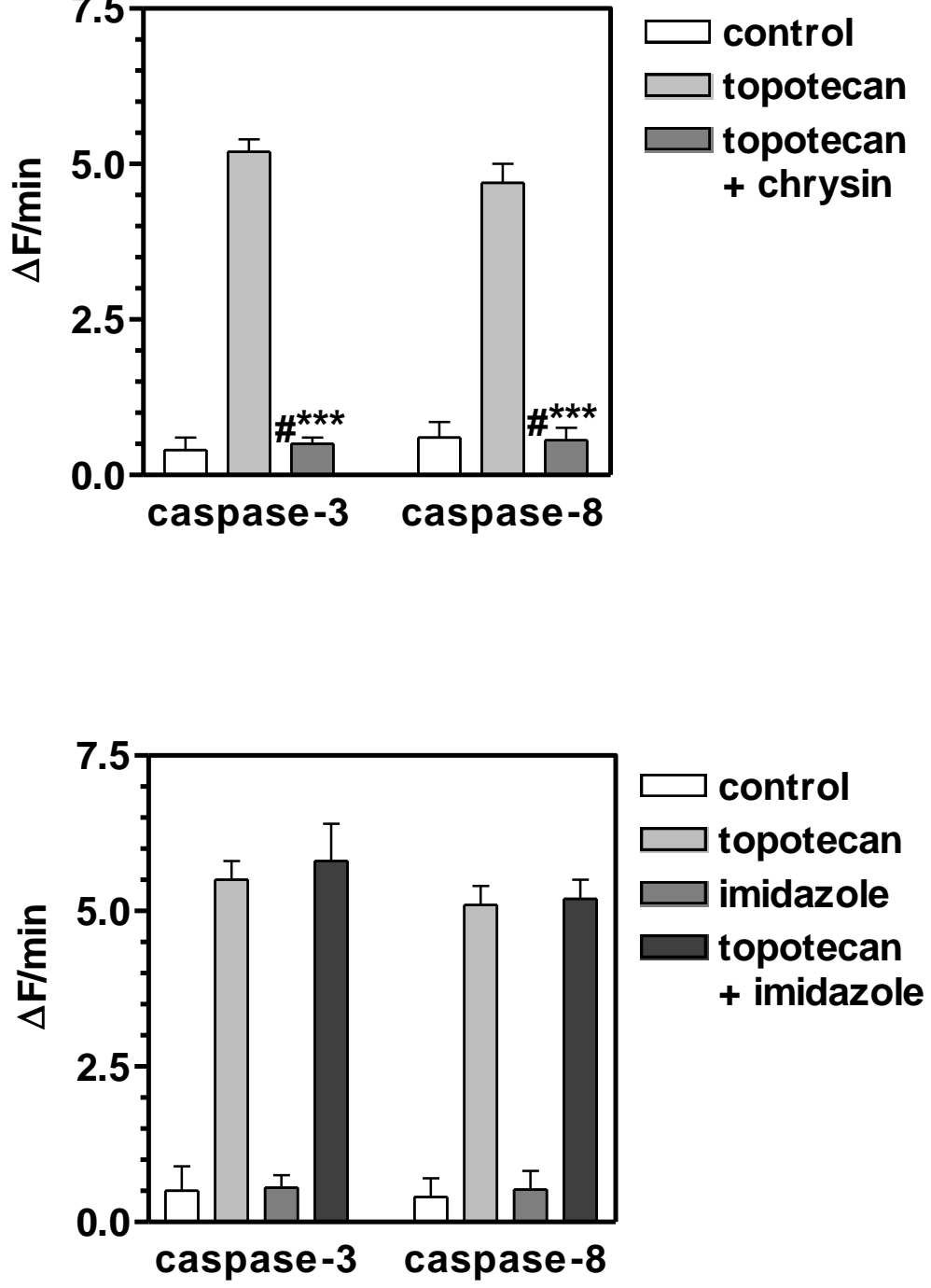

B

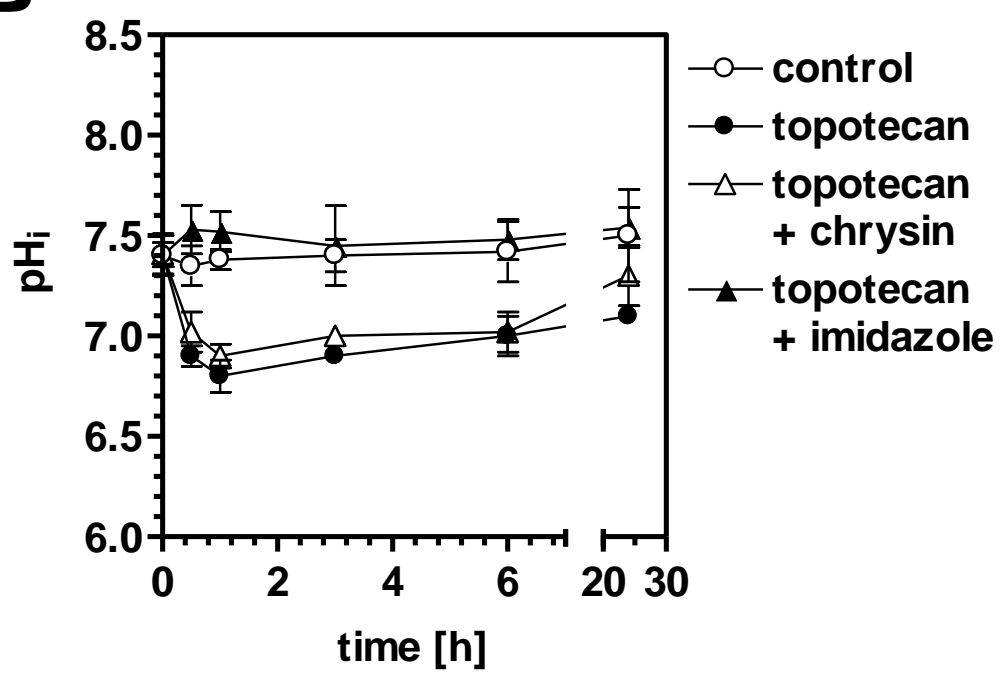

D

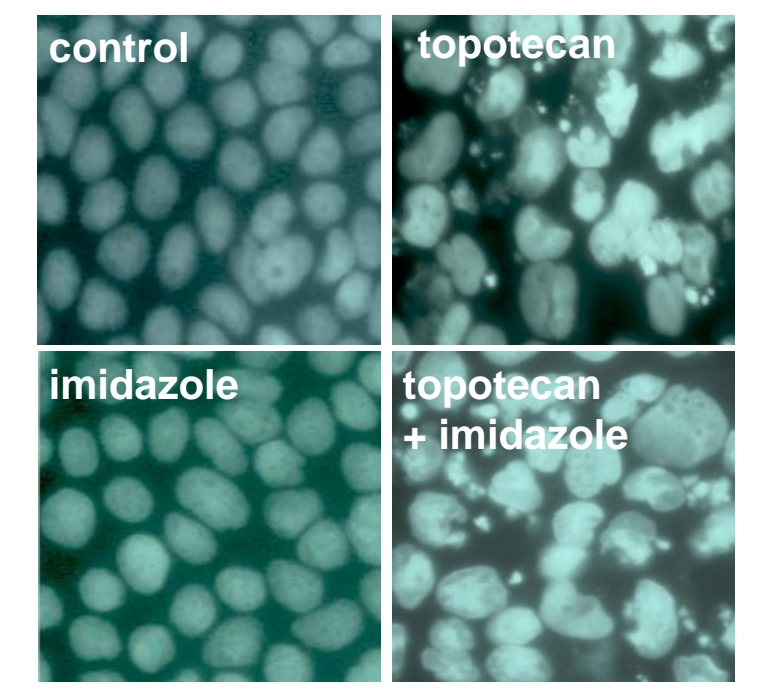


A
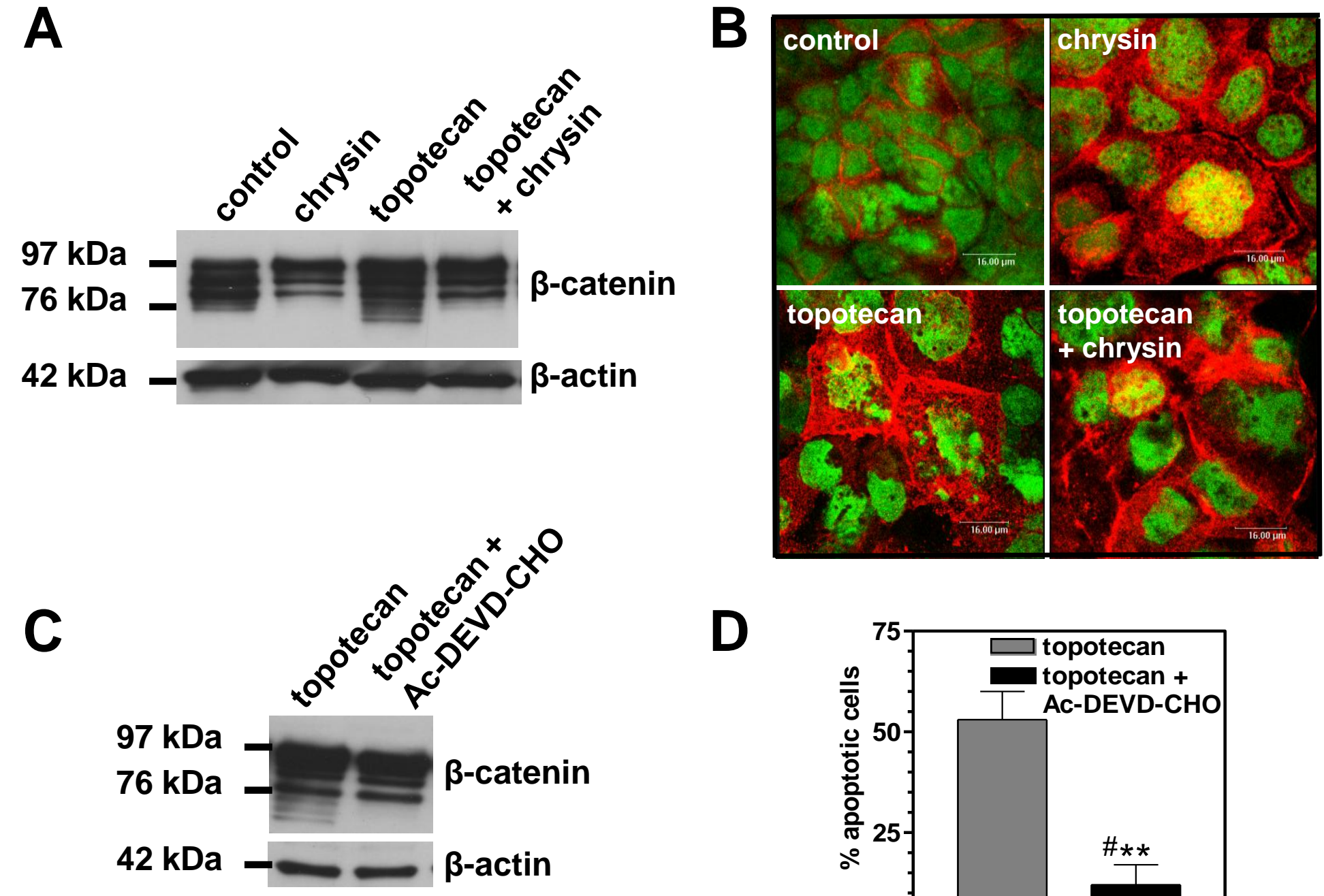

D

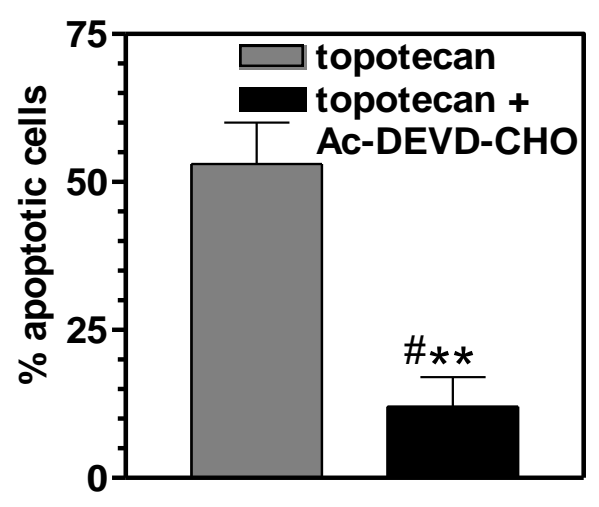



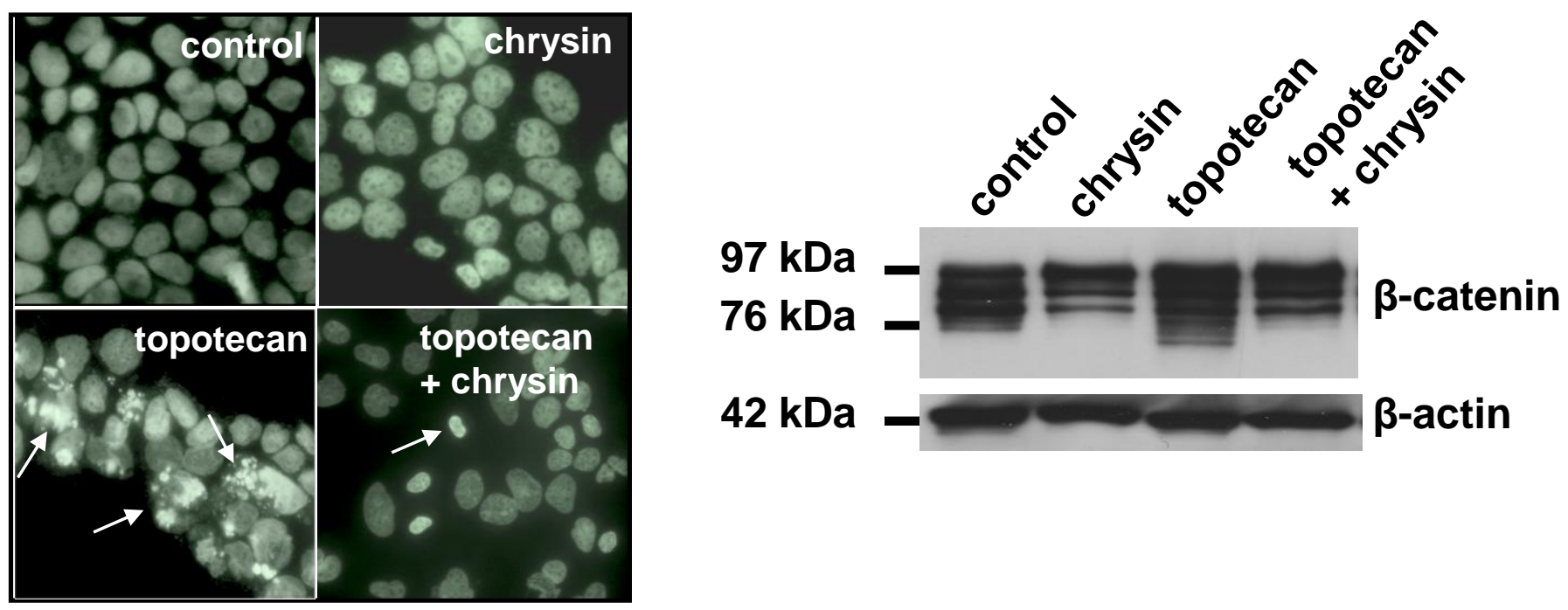

Chrysin potently inhibits topotecan-triggered apoptosis in Caco-2 cells in spite of inhibition of ATP-dependent efflux transporters and comcomitantly increased intracellular drug accumulation by inhibition of caspases and stabilization of B-catenin. 
chrysin or $10 \mathrm{mM}$ imidazole (B). Caspase- 3 and -8 activities as influenced by $10 \mathrm{mM}$ of the base imidazole is given in (C). Absence of effects of imidazole on topotecanmediated DNA-fragmentation is shown under (D).

Fig. 6. Chrysin prevents topotecan-induced cleavage of $\beta$-catenin. Cleavage of $\beta$ catenin was assessed by Western blotting detecting the protein from cells exposed for $48 \mathrm{~h}$ to medium alone (control), or treated with $25 \mu \mathrm{M}$ topotecan, or $250 \mu \mathrm{M}$ chrysin or a combination of $25 \mu \mathrm{M}$ topotecan and $250 \mu \mathrm{M}$ chrysin (A). Cellular localization of B-catenin was detected in cells treated identically as described in (A) by immunocytochemistry (B). In Caco-2 cells treated with $25 \mu \mathrm{M}$ topotecan in the presence or absence of $20 \mu \mathrm{M}$ of the caspase-3 inhibitor Ac-DEVD-CHO cleavage of B-catenin was assessed as described above (C) and apoptosis was determined based on signs of DNA-fragmentation (D). 